\title{
Ekososiaalinen hyve-etiikka
}

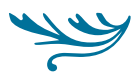

Kestävä kehitys vaatii ekologian ja sosiaalisuuden yhdistävää eettistä ajattelua. Ekososiaalisen hyve-etiikan muotoilun avulla luodaan ymmärrystä siitä, mitä tulevaisuuden kasvatukselta tarvitaan. Kasvatuksella edistettäviä hyveitä on ajateltava maan elonyhteisön piirissä, monimutkaiset keskinäisriippuvuudet muistaen.
\end{abstract}

$\boldsymbol{y}$

AIKAMME EKOLOGISET ONGELMAT, kuten ilmastonmuutos ja biodiversiteettikato, ovat monitahoisia ja hankalia (IPCC 2019). Ekokriisien ratkaisemista on vaikeuttanut länsimaissa vallalla oleva maailmankuva, jonka mukaan ihminen ja hänen kulttuurinsa ovat luonnosta erillisiä (Plumwood 2002). Ekososiaalisten keskinäisriippuvuuksien ymmärrys on jäänyt heikoksi, emmekä ole oppineet vastuullisiksi suhteessa muuhun maapallon elämään. Aikuiskasvatuksessa ja koulutuksessa toistuvat usein käsitys ihmisen ja luonnon erillisyydestä sekä ihmisen näkökulmaa ja etua painottava näkökulma eli antroposentrismi. Länsimaiseen kasvatukseen vaikuttaneessa humanismissa ihminen onkin kaiken mitta ${ }^{1}$ ja itseisarvo.

Humanistisiin arvoihin kytkeytyy liberaalien yksilönvapausajatusten leviäminen uuden ajan vanavedessä. Ihminen otti käyttönsä oikeuden ja vapauden kaikkeen luonnosta saamaansa hyötyyn muiden eliöiden hyvinvoinnista piittaamatta. Teollistumisen myötä 1800-1900-luvuilla ihmisen valta luonnosta alkoi jo uhata elämää maapallolla.

Ihmisen vallan kasvaessa suhteessa muuhun luontoon tarvitaan lisääntyvää vastuullisuutta ja korkeatasoista eettisyyttä. Pelkkä ihmisen toiminnan eettisten ongelmien osoittaminen ja kritiikki eivät riitä ilman parempaa elämäntapaa rakentavia ajatuksia. Onkin pohdittava, miten kasvattaa sellaisia hyveitä, jotka suuntaavat elämäntapaamme kohti ekososiaalista kestävyyttä. Yksi tällainen pyrintö on ekososiaalinen hyve-etiikka, jota muotoilen tässä artikkelissa. Ekososiaalista hyveetiikkaa ei tarvitse muotoilla tyhjästä, vaan hyve-etiikalla on antiikin filosofeihin Platoniin (427-347 eaa.) ja Aristoteleeseen (384-322 eaa.) juontuva vuosituhansien perinne.

Ympäristöhyve-etiikan (environmental virtue ethics $^{2}$ ) tutkimuksessa on osoitettu tarve uudenlaisille elämää ylläpitäville hyveille (esim. Sandler 2013; Cafaro 2010; Jordan \& Kristjánsson 2017; Rolston 2005). Sen keskeinen ihmiskeskeisyyttä kritisoiva 
lähtökohta on hyveiden kohteiden ja kontekstin laajentaminen ihmisistä enemmän-kuin-ihmisen maailmaan ${ }^{3}$. Termit 'enemmän-kuin-ihmisen maailma' (Abram 1996) ja 'ekososiaalinen' viittaavat siihen, että ihmisten on opittava sosiaalisuutta kaikkien elävien olentojen keskuudessa luonnon osana eikä siitä erillään (Pulkki \& Varpanen \& Mullen 2020).

Uudenlaista luontosuhdetta hahmotteleva ekologinen sivistys (Värri 2011) ja ekososiaalinen sivistys (Salonen 2013) ovat kansainvälisestikin huomattavia avauksia ${ }^{4}$ ekokriisien, kuten kuudennen sukupuuttoaallon, ylikulutuksen, saastumisen ja fossiilienergiariippuvuuden, ongelmiin. Ekososiaalinen sivistys lähtee siitä, että ekologiset ja sosiaaliset kysymykset ovat toisiinsa kietoutuneita (Salonen 2013, 42). Ekologiset huolet koskevat esimerkiksi luonnon monimuotoisuutta ja ihmisten epäsosiaalisia eli ekosysteemeille ja muille eliöille haitallisia toimia. Sosiaaliset huolet koskevat eriarvoisia sosiaalisia rakenteita ja epäoikeudenmukaisuuksia, jotka heijastuvat ei-inhimilliseen luontoon. (Salonen 2013, 41-43.) Ekososiaalinen sivistys on ihmisen ja yhteiskunnan vastuullisuutta ja avarakatseisuutta "maan elonyhteisön" (Taylor 1997, 236) keskuudessa.

Ekososiaalisen sivistyksen ja hyve-etiikan suhteen voi ajatella seuraavasti: Ekososiaalinen sivistys on ensinnäkin ajatus ihmisten ja yhteiskuntien kultivoinnista kohti ekologis-sosiaalista henkistä kehitystä ja ekososiaaliseen kestävyyteen suuntautuvaa elämäntapaa. Siihen kuuluu sivistysideaaleja, jotka voidaan luokitella antiikin kolmijaon avulla hyvyydeksi, totuudeksi ja kauneudeksi (ks. Wilenius 2002,67-94; 1982, 22). Toiseksi ekososiaalinen hyve-etiikka tarkastelee hyvän ja onnellisen elämän ylläpitämiseen tarvittavia hyveitä moraalifilosofisesta näkökulmasta, mikä on avuksi 'ekososiaalisen sivistyksen' määrittelyssä. Yhtäältä ekososiaalinen hyve-etiikka auttaa ekososiaalisten sivistysideaalien muotoilussa, toisaalta se kuuluu hyve-etiikan perinteeseen ja keskittyy ekososiaalisessa muutoksessa tarvittavien luonteenhyveiden tutkimiseen.

Artikkelini on avaus ekososiaalisen hyve-etiikan suuntaan kasvatusfilosofisella otteella. Filosofista tarkastelua voidaan kutsua ekososiaalisen kasvatusfilosofian muotoiluksi, millä tässä tarkoitan perinteisen länsimaisen kasvatusfilosofian uudelleentulkitsemista ekososiaalisen ajattelun näkökulmasta (ks. Pulkki 2020; Pulkki \& Varpanen \& Mullen 2020).

Muotoilen ekososiaalista hyve-etiikkaa esittelemällä ekososiaalisen ajattelun historiaa, hyve-etiikan peruskysymyksiä sekä perustaa ja suhdetta kasvatukseen. Ympäristöhyve-etiikan yhteydessä esittelen esimerkillisyyshyve-etiikkaa (exemplarist virtue ethics ${ }^{5}$ ), joka painottaa hyveellisten ihmisten esimerkistä oppimista (Zagzebski 2010). Keskeiset vaikutteeni tulevat ympäristöhyve-etiikan ja ekososiaalisen ajattelun lisäksi ekofeminismistä.

\section{EKOSOSIAALINEN AJATTELU}

Ekososiaalisuus yhdistää kaksi käsitettä: ekologian ja sosiaalisen. Suomen kielessä 'sosiaalisuus' viittaa ihmisten välisiin ja yhteiskunnallisiin suhteisiin, ja siihen kuuluu ajatus heikompiosaisten aseman parantamisesta (Kielitoimiston sanakirja 2020). Tämä ulotetaan ekososiaalisessa ajattelussa ihmisten maailmasta kaikkiin eliöihin. Ekofeminismistä tunnettu naisten ja luonnon kaksoishallinnan (twin domination) käsite auttaa ymmärtämään, kuinka naisia, luontoa ja muita alistetussa asemassa olevia, kuten seksuaalivähemmistöjä ja uskonnollisesti tai etnisesti toisenlaisia, hallitaan saman tyyppisin, toisiinsa liittyvin mekanismein (esim. Warren \& Cheney 1991).

Vaikken keskity sukupuolten tasa-arvon problematiikkaan, painotan ekofeministien avainoivallusta. Sen mukaan naisen ja luonnon hallinnan logiikalla (logic of domination, Warren 1990) on yhteys muuhun huonoon sosiaalisuuteen, kuten lajisortoon ${ }^{6}$ eli spesisismiin, rasismiin ja jälkikolonialistiseen ${ }^{7}$ eriarvoisuutta ylläpitävään globalisaatioon (esim. HattenFlisher \& Martusewicz 2018).

Ekofeminismin yhteys ekososiaaliseen ajatteluun on ilmeinen: ekososiaalinen tuhoavuutemme vähenee irtautumalla sortavista vallankäytön muodoista ja niihin sisältyvistä ajattelumalleista (ks. Harvester \& Blenkinsop 2010). Nähdäkseni ekososiaalisen ajattelun ydin on ekofeministinen, sillä hyvä sosiaalisuus ihmisten kesken mahdollistaa sosiaalisuutta maan elonyhteisön keskuudessa (ks. esim. Warren 1990; Harvester \& Blenkinsop 2010). 


\section{EKOSOSIAALINEN}

\section{TUHOAVUUTEMME V ̈̈HENEE,}

\section{KUN IRTAUDUMME SORTAVISTA}

\section{VALLANK ̈̈̈TÖN MUODOISTA}

JA NIIHIN SISÄLTYVIST $\ddot{A}$

\section{AJATTELUMALLEISTA.}

Ekologian käsite tulee kreikan sanoista oikos ja logos, joista edellinen tarkoittaa kotia, ja jälkimmäinen voidaan suomentaa järjeksi (esim. Väyrynen 2006, 114-115). Ekologia tieteenä tutkii organismien suhteita ja vuorovaikutuksia toisiinsa sekä näiden elollisiin eli bioottisiin ja elottomiin eli abioottisiin ympäristöihin (esim. Scheiner \& Willig 2008; Crowley 2010). Ekologialla en tarkoita vain ekologia-tiedettä vaan myös arkkitehtuuria, humanistisia tieteitä, taloutta ja tuotantoa (Morton 2010, 4). Ekologia sisältää kaikki ne tavat, joilla elämme yhdessä ja vuorovaikutuksissa muiden elävien ja elottomien olioiden kanssa (Morton 2010, 1-5; Pulkki \& Varpanen \& Mullen 2020).

Ekososiaalisen ajattelun historiallisia lähtökohtia ovat systeemiajattelu ja ekokriittinen ajattelu (Matthies \& Närhi \& Ward, 2001, 20-21). Yleisessä systeemiajattelussa ihmisyhteisöjen toiminnan ja biologisten systeemien välillä voidaan nähdä analogisia toimintaperiaatteita. Systeemiajattelussa ekologiset, sosiaaliset ja fysikaaliset ulottuvuudet ovat vuorovaikutusverkostossa keskenään. Yleisessä systeemiteoriassa ihmisiä ei nähdä erillisinä yksilöinä vaan sosiaalisen järjestelmän osina. Ekokriittinen ajattelu sai vaikutteita 1970-luvun ja sen jälkeisistä ympäristöliikkeistä, kestävän kehityksen ideasta ja ympäristösosiologiasta. 1970-luvun jälkeen saksalaisessa sosiaalityössä ja sosiaalipolitiikassa tapahtui paradigman muutos sosiaalisesta kysymyksestä ekososiaaliseen problematiikkaan. Ekososiaalisuuden käsitteen otti käyttöön saksalainen sosiaalipolitiikan professori Michael Opielka (1956-) huomatessaan, ettei sosiaalisia kysymyksiä voinut tarkastella irrallaan ekologisista kysymyksistä. Opielkan ja saksalaisen sosiaalitieteen keskeinen huomio oli se, että ekologinen ymmärrys mahdollistaa ihmisten sosiaalisen hyvinvoinnin $^{8}$. (Matthies \& Närhi \& Ward, 2001, 20-26.)

Suomeen ekososiaalista ajattelua ovat tuoneet ainakin sosiaalityön professorit Aila-Leena Matthies ja Kati Närhi (esim. Matthies \& Närhi \& Ward 2001). Kasvatuksen ja koulutuksen alalla Arto O. Salonen ja Marjatta Bardy (2015) ovat luoneet ekososiaalisen sivistyksen käsitteen monitieteisen ekososiaalisen lähestymistavan pohjalta. Ekososiaalisen hyve-etiikan sekä ekososiaalisen sivistyksen käsitteet ovat velkaa niitä edeltävälle ekologisen sivistyksen (Värri 2011; 2018) käsitteelle. Olennainen edistysaskel oli ekososiaalisen sivistyksen kirjaaminen peruskoulun opetussuunnitelman perusteisiin (POPS 2014).

'Ekososiaalisuus' on laaja sateenvarjokäsite, jossa painottuvat ekologisten ja sosiaalisten seikkojen keskinäisriippuvuus ja ihmisen sosiaalisuuden laatujen parantaminen ekologisten ongelmien ratkaisemisessa (Närhi \& Matthies 2001, 30). Mutta ihmisten ja muiden eliöiden sosiaalisuus sekä ekologia ovat monimutkaisia, lukemattomista teemoista koostuvia asiakokonaisuuksia. Yleisen ekososiaalisen teorian kehittäminen ekologian ja ihmisyhteiskuntien suhteista ei ole näin ollen realistista (Haila 2009). Yhtä kaikki voimme puhua esimerkiksi ekososiaalisesta näkökulmasta, tutkimusstrategiasta ja ajattelusta (Haila 2009) ja katsoa myös hyve-etiikkaa ekososiaalisesta perspektiivistä.

\section{HYVE-ETIIKKA}

Hyve-etiikka on filosofisen etiikan tutkimusala, jossa pohditaan hyvän ja pahan sekä oikean ja väärän kysymyksiä siitä näkökulmasta, miten moraalisesti ihanteellinen eli hyveellinen ihminen toimii (esim. Friman 2004). Hyveitä koskeva teoretisointi liitetään yleensä Aristoteleen ajatteluun, ja hyve-etiikka ehdittiin välillä jo lähes unohtaa (Huttunen \& Kakkori 2007).

1900-luvun etiikan teoriassa hallitsi hyve-etiikan sijaan kaksi teoriaa: utilitarismi ja deontologia. Utilitarismin mukaan moraalisen teon olennainen mittari on maksimaaliselle ihmismäärälle tuotettu suurin mahdollinen hyvä. Se on seurausetiikkaa, jonka ongelmana on kylmä hyötylaskelmointi, kun punnitaan vaikkapa kaivoksen tuomaa aineellista vaurautta 
suhteessa vesistöjen saastumiseen ja uhanalaisten lajien tuhoutumiseen. Deontologiassa eli velvollisuusetiikassa puolestaan järki osoittaa meille yleispätevät periaatteet, joita tulee kaikissa tilanteissa noudattaa. Tunnetuin velvollisuusetiikan esitys on saksalaisfilosofi Immanuel Kantin (1724-1804) kategorinen imperatiivi: toimi aina siten, että toimintatapasi voitaisiin yleistää kaikkia koskevaksi säännöksi. (Vainio 2016; Cafaro 2010.)

Hyve-etiikka esitetään usein vaihtoehtona utilitarismille ja deontologialle (Vainio 2016), ja kysymys elämän suunnasta sekä tarvittavista hyveistä onkin kasvatusfilosofian ytimessä (esim. Wilenius 1987). Tunnetuimpiin hyve-etiikan tutkijoihin kuuluvan Alasdair MacIntyren (2002a, 190) mukaan Kantin universaaleissa moraalisäännöissä on pikemminkin kysymys siitä, mitä meidän ei tulisi tehdä kuin mihin elämässä pitäisi suuntautua. Yksi kritiikin kohde on ollut se, että myös moraalisääntöjä ja velvollisuuksia noudattava henkilö voi olla epähumaani ja julma (Vainio 2016; MacIntyre 2002b). Monet ovat arvostelleet etiikan tutkimusta siitä, että ihminen ei moraalisia päätöksiä tehdessään käytännössä pohdi asioita universaalien sääntöjen näkökulmasta järjellisesti vaan reagoi tilanteisiin ennalta oppimiensa asenteiden, tunteiden, arvojen ja toimintamallien pohjalta (esim. Varela 1999; ks. Friedman 2000).

Hyveellinen toiminta edellyttää muutakin kuin sääntöjen seuraamista (MacIntyre 2002b, 93). Hyveetiikassa moraalisten sääntöjen ja velvollisuuksien taustalla on syvempi taso, josta moraaliset tai moraalittomat teot kumpuavat, nimittäin tekijän luonne (character). Toisin kuin utilitarismissa ajatellaan, teon oikeellisuus ei aina riipu sen hyvää tekevyydestä mahdollisimman monelle eikä deontologian mukaisesti universaalien moraaliperiaatteiden noudattamisesta. (Vainio 2016.)

Teko on oikea, jos se ilmentää hyvettä ja on motivoitunut hyveestä käsin (Vainio 2016). Opettajuudesta voidaan esimerkiksi sanoa kasvatustieteen professori Michael Fullanin $(1993,12)$ tavoin: "Hyvän opettajan pintaa raapaisemalla löytyy moraalinen tarkoitusperä9." Kasvattaja on aina hyve-eettinen toimija.

Hyveet ovat hyviä, tosia ja kauniita luonteenpiirteitä, mutta filosofi voisi kysyä mihin ne perustuvat. Esimerkiksi uskonto ja kansallisvaltioaate ovat perin- teisiä hyveiden perustoja. Hyveitä on käytetty valtion ja uskonnon tarpeisiin toisinaan autoritäärisen kurittamisen merkeissä (Tessman 2005). Valtaosassa 1700-1800-lukujen suomalaisissa kasvatustekstejä puhuttiin vanhaluterilaisista hyveistä ja paheista perisyntiopin hengessä. Tällöin ihminen oli syntyessään turmeltunut, kykenemätön ja haluton hyvään sekä velvollisuuksiensa täyttämiseen. Ihmisen synnynnäinen paha oli kitkettävä ankaralla kasvatuksella pois. Kasvattajan tehtävä oli lisäksi juurruttaa kasvatettavaan hyvää, vaikka tämä usein tapahtui epäsuorasti paheita kitkemällä. (Launonen 2000, 87.) Nykyisin esimerkiksi ekorepublikaanit painottavat ympäristökansalaisuutta, joka mahdollistaa yhteisöllisen kansalaishyveiden uudelleenarvioinnin ja tähän perustuvia projekteja (Cannavo 2016).

2000-luvun akateeminen hyve-etiikka poikkeaa ratkaisevasti vanhaluterilaisesta kasvatuksesta. MacIntyre pitää Hyveiden jäljillä -teoksessaan (2004) hyveiden perustana yhteisöjä ja niiden käytäntöjä. Hyveet rakentuvat ihmisten keskuudessa monimutkaisissa sosiaalisissa prosesseissa jaetuiksi käsityksiksi toivottavasta ihmisyydestä. Nykyajattelussa hyveet perustetaan usein sosiaalisiin käytäntöihin ja ihmisten väliseen yhteistyöhön sekä yhteisöihin ja näissä opittuihin identiteetteihin. Rakennamme minuuttamme yhteisössä olevien kertomusten varaan. Myös traditiot kantavat käsityksiä ihmisten arvostetuista luonteenpiirteistä eli hyveistä. (Sihvola 2004, 11; Sihvola 2003, 21-22; MacIntyre 2004.) Aikuiskasvatuksen käytäntöjä ja traditioita olisi ekososiaalisen hyve-etiikan näkökulmasta kultivoitava sellaisiksi, että elämää ylläpitävä vuorovaikutus rakentuisi osaksi luonteenhyveitämme.

\section{HYVEIDEN PERUSTA JA KASVATUS?}

Ekososiaalista hyve-etiikkaa voidaan perustaa jossain määrin ekologian varaan (Pulkki 2017, 105). Koska ekologialla ei ole omaa ääntä, sitä ja ihmisen hyvää elämää on soviteltava yhteen ainutlaatuisissa ajoissa ja paikoissa (Pulkki \& Varpanen \& Mullen 2020). Ekologia ei ole ainoa hyveiden perusta ${ }^{10}$, vaan demokraattinen yhteisö määrittelee hyveensä ekologisesti tai epäekologisesti ${ }^{11}$. Demokratia on ekososiaalisen 


\section{Hyveisisn SUUNTAUTUVA}

\section{KASVATUS KESKITTYY}

LUONTEENHYVEIDEN JA

\author{
INTELLEKTUAALISTEN
}

HYVEIDEN OMAKSUMISEEN.

sivistyksen keskeinen arvo, mutta ei ole takeita siitä, että demokratia johtaa ekososiaalisesti kestävään elämään ${ }^{12}$. Demokraattinen valtio voi pitää esimerkiksi ilmastonmuutosta faktana (IPCC 2019) eikä mielipidekysymyksenä ja luoda toimenpideohjelmia ekokriisien voittamiseksi ja ympäristökansalaisuuden kehittämiseksi kasvatus- ja koulutusinstituutioiden avulla. Demokraattinen yhteiskunta voi ottaa oppia Platonin Valtiossa esittämästä ajatuksesta, että kansalaisia tulee kasvattaa hyveellisyyteen (1999). Tässä on kuitenkin oltava tarkkana, että ei ajauduta liian autoritäärisen yhteiskuntakehityksen tielle, vaan demokraattinen keskustelu ja moniäänisyys säilyvät keskeisinä arvoina (Pulkki 2017, 105). Hyve-etiikka perustuu näkemyksiin hyvästä ja onnellisesta elämästä, mutta hyvää elämää ei voi lopullisesti määritellä (Toiskallio 2016, 48; Värri 1994). Hyveistä ja paheista sekä hyvästä elämästä on keskusteltava aina uudelleen uusissa tilanteissa.

Kasvatuksen empiiris-analyyttisessa kielessä hyveen käsite voidaan kokea ongelmallisena. Hyveet ovat normatiivisia käsityksiä jonkin yhteisön arvostamista luonteenpiirteistä (esim. MacIntyre 2004; Bassham 2013), kun taas ankaraa tieteellisyyttä painottava tutkija suhtautuu arvoihin epäillen. Tieteen tulee toimia tosiasioiden, ei arvojen maailmassa. Kasvatuspäämäärät ovat arvoihin sidoksissa ja välttämätön osa kasvatusta. Kasvatus tähtää tulevaisuudessa hyvinä asioina pidettyjen tavoitteiden saavuttamiseen (esim. Wilenius 1987). Jos sivuutamme tämän perustavan ulottuvuuden, saatamme tuottaa kasvatusta, joka toimii puhtaan välinerationaalisesti ja keskittyy esimerkiksi vientiteollisuuden kilpailukyvyn tavoitteisiin. Näin voi unohtua kasvatettavan hyvän ja ekososiaalisen hyvän edistäminen kasvatuksen tärkeimpinä tavoitteina.

Aristoteleen $(2005,27)$ kahtiajakoa käyttäen hyveisiin suuntautuva kasvatus keskittyy luonteenhy- veiden ja intellektuaalisten hyveiden omaksumiseen. Hyve-eettinen lähestymistapa kasvatuksen ja koulutuksen kysymyksiin keskittyy toisin sanoen inhimilliseen kasvuun ja ihmisen luonteen kehittymiseen (Bassham 2013, 11-12). Koulutuksen tuottamat muodolliset kvalifikaatiot ja kompetenssit sekä tutkinnot ovat kiinnostavia, mutta "sydämen sivistys" (esim. Ojanen 2000) vieläkin tärkeämpää.

\section{YMPÄRISTÖHYVE-ETIIKKA JA ESIMERKILLISYYSHYVE-ETIIKKA}

Ympäristöhyve-etiikassa pohditaan ekologisesti kestävien käytäntöjen omaksumiselle olennaisia hyveitä (esim. Cafaro 2010; Sandler 2013; Wensveen 2000). Sen ydinkysymys on filosofian professori Ronald Sandlerin (2013) mukaan siinä, mikä tekee luonteenpiirteestä ekologisen hyveen tai paheen. Ympäristöä koskevat hyveet, esimerkiksi kasvissyönti, lihasvoimin liikkuminen ja luonnon kunnioitus, ovatkin yhä useammin keskustelun aiheena. (Wensveen 2000, 4-7.)

Ympäristöhyve-etiikkaa ja ekososiaalista hyveetiikkaa voi lähestyä pedagogisesti rakentavalla tavalla tutustumalla luonnonsuojelun kannalta ansiokkaiden henkilöiden toimiin. Kansainvälisesti tunnetut ympäristöfilosofit, kuten Henry Thoreau, Aldo Leopold ja Rachel Carson, nousevat tällöin esiin (Sandler 2013). Keskustelu syväekologiasta ja esimerkiksi Pentti Linkolasta on suomalaisille kiinnostavaa (Vadén 2008; Takkinen \& Takkinen 2015). Peräänantamattoman johdonmukaisuuden filosofi-kalastaja-ornitologi nousi vanhemmiten mediahuomioon demokratianvastaisista näkemyksistään. Voisiko elämä voittaa -kirjassaan $(2004,362)$ hän puhui demokratiasta "kuoleman uskontona", joka on "kaikista tunnetuista onnettomin yhteiskuntajärjestelmä". Linkolalle luonnon tuho oli toistuva henkilökohtainen tragedia ja trauma (ks. Kylänpää 2017), mikä vaikutti osaltaan siihen, että 1960-luvun pasifistista kuoriutui myöhemmin ekodiktatuurin kannattaja (ks. Vadén 2008). Linkolan synkentyneen ajattelun taustalla oli luonnontieteellisesti orientoituva, ihmistieteitä puutteellisesti tunteva ajatus väestönkasvusta päällimmäisenä ekologisena ongelmana. Esimerkiksi kasvatus ei ollut hänelle merkittävä toivon horisontti. 
Hyveellisyydestään tunnetut ihmiset, kuten äiti Teresa ja Mahatma Gandhi, ovat olleet moraalisesti kohottavia esikuvia ${ }^{13}$. Niin uskonnollisissa kuin akateemisissakin yhteyksissä on pidetty viisaana hakeutua esikuvallisten gurujen ja maineikkaiden professoreiden vaikutuspiiriin. Hyveellisten ihmisten esimerkeistä kiinnostunutta esimerkillisyyshyve-etiikkaa voidaan ajatella sekä ympäristöhyve-etiikkana että eräänlaisena ikiaikaisen, perenniaalisen pedagogiikan (Wilenius 2002, 91-94) muotona. Kaikkina aikoina on kerrottu inspiroivia tarinoita sankareista ja ihailua ansaitsevista ihmisistä. 2000-luku tarvitsee omanlaisia ekososiaalisesti hedelmällisiä tarinoita, ja ruotsalainen ilmastoaktivisti Greta Thunberg onkin innoittava esimerkki monelle.

Esimerkillisyyshyve-etiikan ytimessä on moraalisesti esikuvallisten ihmisten ihailua seuraava jäljittely (Zagzebski 2010). Kasvatuksen kannalta on olennaista huomata, ettei kaikki ihailu kohdistu moraaliseen erinomaisuuteen. Kasvatus ei toimi millaisten tahansa tarinoiden ja ihmisten ihailun kautta (Platon 1999, 74-77'14). Sen tärkeimpiin asioihin kuuluu hyveisiin johdattavien samaistuttavien tarinoiden kertominen. Valheellisia ja rumia tarinoita vaikkapa toisiaan vastaan juonivista ja taistelevista jumalista tai nykyaikana tosi-tv-julkkiksista - tuleekin Platonin mukaan välttää. Huono kasvatus ja väärämieliset tarinat vievät valtiota ja sen kansalaisten kehitystä huonoon suuntaan. (Platon 1999, 74-77.)

Kun Linkolan myöhempää ajattelua leimaa ekologia ilman hyvää sosiaalisuutta, ekososiaalisen hyveetiikan yksi pedagoginen lähtökohta on sosiaalisesti taitavat esikuvat, jollaisena voidaan pitää omavaraiselämäntapaa opettavaa ja tutkivaa Lasse Nordlundia (Vadén 2009). Hän on esimerkki ainakin monitahoisten omavaraisuustaitojensa ja ennakkoluulottoman kokeilumentaliteettinsa vuoksi (ks. Nordlund \& Dorf 2014). Ekososiaalisen hyve-etiikan kannalta Nordlundissa on kiinnostavaa hänen kykynsä yhdistää sosiaalisuus ja ekologisuus. Hän ei ole yksinpärjäämisen eetosta edustava survivalistisankari tai ekososiaalisille muutospyrinnöille kintaalla viittaava uraohjus vaan Omavaraopiston opettajan, perheenisän, omavaraisuustaitojen tutkijan ja harrastajan rooleja yhdistävä esikuva.

\section{EKOFEMINISMI}

Ekofeminismi on ekososiaalisen hyve-etiikan tarpeellinen perusta, vaikka ekofeministit ovat arvostelleet perinteistä hyve-etiikkaa naisten yhteiskunnalliseen asemaan kuuluvien kysymysten sivuuttamisesta (ks. esim. Dillon 2017; Berges 2015; Tessman 2005). Alistavat valtasuhteet ovatkin vääristäneet ja haitanneet sekä alistajien että alistettujen moraalikehitystä (Tessman 2005, 4-6). Perinteisen mieskeskeisen, androsentrisen, hyve-etiikan ongelmista huolimatta on mahdollista muotoilla hyve-etiikkaa, joka ei etuoikeuta miesnäkökulmaa, ylläpidä eriarvoisia valta- ja yhteiskuntarakenteita eikä sivuuta ihmissuhteisiin liittyviä tunteita ja velvoituksia (esim. Berges 2015; Dillon 2017). Ekofeminististä hyve-etiikkaa voidaan myös ajatella mieskeskeistä hyve-etiikkaa tasapainottavana voimana ${ }^{15}$ (ks. esim. Gomes \& Kanner 1995).

Ekososiaalisen hyve-etiikan keskeinen ekofeminismistä tuleva ajatus on länsimaisen kulttuurin naisten ja luonnon alistaminen samanlaisilla ajattelumalleilla (esim. Warren \& Cheney 1991). Kokeellisen menetelmän ensimmäisen teoreetikon Francis Baconin (1561-1626) mukaan luonto olikin nainen, joka tiedemiehen oli valloitettava: "metodisesti ja systemaattisesti riisuttava äiti luonto, paljastettava hänen salaisuutensa, tunkeuduttava hänen syliinsä ja siten pakotettava hänet täydelliseen alistumiseen" (von Wright 1987, 49, 62). Hierarkkiset dualismit, kuten järki-tunne, mieli-ruumis, mies-nainen, kulttuuri-luonto, aktiivinen-passiivinen ja kehittynyt-primitiivinen, sisältävät ajatuksia miehisen, järjellisen, kulttuurisen ja aktiivisen ylemmyydestä suhteessa naiselliseen, tunteelliseen, luontoon kuuluvaan ja passiiviseen (Martusewicz, Lupinacci ja Edmundson 2015, 64).

Oletetusti järjellinen ja aktiivinen mies on ottanut pidäkkeettä ja armotta luonnon käyttöönsä modernin tieteen ja teknologian avustuksella. Suositussa kantilaisessa ajattelutavassa luonnolla ei ole itseisarvoa, koska vain ihmisellä on kyky autonomiseen järjenkäyttöön (Aaltola 2013, 18). Epäsosiaalista käyttäytymistä ei-inhimillistä luontoa kohtaan on oikeutettu ihmisen järjellisyyden ja mainittujen hierarkkisten dualismien avulla. Luonto on ymmärretty 


\section{HYveIt $\ddot{A}$ VOIDAAN PIT $\ddot{A}$}

\section{KASVATUSIDEAALEINA,}

\section{JOITA ON 2000-LUVULLA}

\section{AJATELTAVA EKOSOSIAALISIN PAINOTUKSIN.}

valistusajalta meidän päiviimme asti usein mekanistisena ja elottomana kokonaisuutena eikä niinkään orgaanisena kokonaisuutena, jonka hyvinvoinnista tai tunteista tulisi välittää (Merchant 1983; Donovan 2013, 191). Ei ihme, että muodollinen teknistaloudellis-tieteellinen sivistys on monesti asetettu sydämen sivistyksen edelle.

Yhtäältä länsimainen autonomiaa painottava maailmankuva sekä ajatukset universaalista tieteestä ja vapaudesta ovat tähdänneet erilaisten riippuvuuksien ylittämiseen. Feminististen hyveiden ytimessä on toisaalta keskinäisriippuvuuksien, velvoittavien suhteiden, tunteiden, tasa-arvoisten ja ei-elitististen sosiaalisten rakenteiden painotus. (Mies \& Shiva 2005, 18.) Feministit ovat kritisoineet universaalia kantilaista etiikkaa, joka toimisi kaikille kaikissa tilanteissa samalla tavalla (esim. Friedman 2000). Universaali etiikka kadottaa moraalisubjektien väliset erot, jotka juontuvat heidän erilaisista fyysis-psyykkis-sosiaalisista tilanteistaan aikansa kulttuurisesti ja historiallisesti rakentuneissa yhteiskunnallisissa järjestyksissä. Ekofeministien ekososiaaliseksi tulkittavissa oleva perusoivallus on siinä, että ekologiseen kestävyyteen on edellytykset vain yhteiskunnalla, jossa vältetään eriarvoisuutta, alistussuhteita, rasismia, seksismiä ja marginaaliryhmien huonoa kohtelua (Harvestern \& Blenkinsop 2010; Hatten-Flisher \& Martusewicz 2018).

\section{EKOSOSIAALISET HYVEET}

Ekofeministit ovat muotoilleet hyveitä, joita tarkastelen ekososiaalisina: uusi ekologisen herkkyyden kieli, koko elämän yhteisöön laajentuva solidaarisuus, uusi affektiivinen ja suhteita painottava ihmisälykkyys, epäjärjestelmällisiä suhteita korostavat käytännöt (koska "järjestys" tarkoittaa hierarkkista hallintaa ${ }^{16}$ ) ja ympäristön kunnioitus. Maternaaliseen etiikkaan kuuluu kunnioitus elämän prosessia kohtaan ilman pyrkimystä hallita kaikkea. Huolenpito, tarkkaavainen rakkaus ja vastuullisuus ovat kiintoisia ekofeministisiä hyveitä. (Donovan 2013, 200-205; Gomes \& Kanner 1995; Sewall 1995; Dillon 2017; Noddings 1986.) Ekososiaalisen hyveetiikan tunnuspiirre on siten rakentava vuorovaikutus yhteisöissä.

Valtaosaa "maan elonyhteisön" (Taylor 1997, 236) jäsenistä emme voi rajallisilla aisteillamme havaita. Esimerkiksi ihmisen terveys ja immuniteetti riippuvat moninaisista suolistobakteereista. Tarvitaankin suunnanmuutos Francis Baconin "äiti luonnon täydellisestä alistamisesta” kohti näkyvää ja näkymätöntä elämää kunnioittavia hyveitä sekä kenties lumouksen palauttamista elämään ja sen ylläpitämiseen (Mies \& Shiva 2005, 18). Elon ja elollisuuden entistä tarkempi havainnointi, "ekologisen herkkyyden kieli" ja "suhteita painottava ihmisälykkyys" (Donovan 2013; ks. Sewall 1995) voivat osoittaa tietä kohti entistä laajempaa ymmärrystä elämästä ja sen ylläpitämiseen tarvittavista hyveistä. Ekososiaalisten hyveiden oppimisessa tarvitaan havaintokyvyn kultivointia sekä tuntevaa ja aistivaa ekologiaa (sentient ecology) (Ingold 2000, 22).

Ekososiaalisia hyveitä voidaan ekofeminismin ja ympäristöhyve-etiikan lisäksi muotoilla ainakin ekososiaalisen ajattelun, ekofenomenologian ja ekososiaalisen sivistyksen tuomin virikkein. Esimerkiksi ekososiaalisesti ajatteleva Thomas Crowley (2010) puhuu ekososiaalisesta kukoistuksesta, sosioekologisesti suuntautuneesta käytännöllisestä järjestä (fronesis), keskinäisriippuvuuksien tajusta, joustavasta ja dualismeja monitahoisemmasta ajattelusta sekä biofiliasta, rakkaudesta kaikkea elävää kohtaan. Ekologisen sivistyksen yhteydessä Arto O. Salonen (2012) on puhunut globalisoituneen todellisuuden hahmottamisesta, eettisen huolenpidon laajuudesta ja osallisuuden merkityksestä. Tärkeitä ovat lisäksi henkinen kehittyneisyys ja kypsyys sekä vapauden ja vastuun tasapaino, ekologinen eheys, ekologinen monimuotoisuus sekä myötätunto, demokratia ja rauha (Salonen 2012; Pulkki 2020). 


\section{POHDINTA}

Ekososiaalisen hyve-etiikan muotoilu on ajankohtaista ekokriisien aikakaudella, jotta voimme kasvatuksella rakentaa nykyistä kestävämpää elämäntapaa ja nähdä tarkemmin kasvatuksella tavoiteltavia päämääriä. Hyveitä voidaankin pitää kasvatusideaaleina, joita 2000-luvulla on ajateltava ekososiaalisin painotuksin.

Määrittelen ekososiaalisen hyve-etiikan eettisen tutkimuksen alaksi, joka tarkastelee ekologisissa ja sosiaalisissa yhteyksissä tarvittavia hyveitä, kuten keskinäisriippuvuuksien tajua, huolenpitoa, monitahoista ajattelua ja käytännöllistä järkeä ${ }^{17}$. Sen kannalta hyveet voidaan määritellä eettisessä mielessä sosiaalisesti arvostetuiksi luonteenpiirteiksi (ks. MacIntyre 2004), mutta sosiaalisuus on tulkittava kaikkien eliöiden väliseksi. Ekososiaalisessa ajattelussa ihmisellä on erityinen vastuu koko maapallon elonkehään vaikuttavista toimistaan.

Ekososiaalisessa hyve-etiikassa on olennaista tarkastella ja ymmärtää niitä sosiaalisia käytäntöjä ja historiallisia kehityskulkuja, joissa ajatukset hyveellisestä ja paheellisesta toiminnasta muotoutuvat (esim. Dillon 2017; Tessman 2005). Sen tutkimustulosten avulla voidaan muotoilla ympäristökansalaisuutta ja siihen liittyvää kasvatusta, jotta tulevaisuuden demokraattiset toimijat voivat toimia ekososiaalisen kestävyyden hyväksi.

Esimerkillisyyshyve-etiikka on aikuiskasvatuksellisesti kiinnostava lähestymistapa ekososiaaliseen hyve-etiikkaan. Elävien esimerkkien puutteessa elokuvat, kuten Steven Soderberghin Erin Brockovich sekä Todd Haynesin Peitelty totuus, toimivat esimerkkeinä ja inspiraationa. Ne ovat tositarinoita terveyttä uhkaavia suuryrityksiä vastaan taistelevista ihmisistä, jotka voivat innoittaa ekososiaalista hyveellisyyttä ilmentäviin toimiin ja herätellä ekososiaalista omaatuntoa (Pulkki 2020).

Ekososiaalisten hyveiden kultivoinnin kannalta onkin tärkeä luoda uudenlaisia, elämän yhä herkempään ymmärrykseen ja edistämiseen tähtääviä narratiiveja. Vanha sankariepiikka väkivallalla, nokkeluudella ja lujalla tahdolla nujerrettavasta vihollisesta ei toimi ekokriisien yhteydessä (Pulkki 2017). Keskeisiä hyveitä ekososiaalisessa hyve-etiikassa on taito herkkään elämän havainnointiin (Ingold 2000), jotta ekologisesti tuhoisiin hankkeisiin ei tarvitsisi lähteä.

Omavaraisuusopettaja Lasse Nordlundin esikuva on ekososiaalisten hyveiden oppimisen kannalta arvokas siksi, että se antaa omaan kulttuuriimme ja omiin biologisiin alueisiimme ${ }^{18}$ sopivia esimerkkejä kestävästä elämäntavasta (ks. Nordlund \& Dorf 2014; Vadén 2009). Useimmat ekologisesti tuhoavat toimet on tehty "kehittyneen" teknologian ja tieteen avulla osana järjellisiä prosesseja. Nordlundin omavaratoiminta osoittaa, että meillä on jo käytäntöjä, joissa sosiaaliset ja ekologiset näkökohdat huomioidaan. Pentti Linkolan syväekologian sudenkuoppa oli ekologia, joka ei osannut vastata sosiaalisuuden vaatimuksiin. Ekososiaalinen hyve-etiikka suuntautuu sellaisen tasapainon tavoitteluun, jossa ihmiselle on oma paikkansa maan elonyhteisössä.

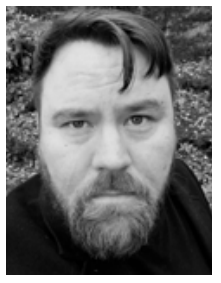

JANI PULKKI

$\mathrm{KT}$, tutkija

Ekososiaalisen kasvatusfilosofian luonnos -hanke 2019-2022 (https://poisedresearch.com) kasvatustieteiden ja kulttuurin tiedekunta

Tampereen yliopisto

(D) https://orcid.org/0000-00017058-5364

\section{LÄHTEET}

Aaltola, E. (2013). Johdanto: Ihminen, eläin vai molemmat? Teoksessa E. Aaltola (toim.) Johdatus eläinfilosofiaan. Helsinki: Gaudeamus, 9-27.

Abram, D. (1996). The Spell of the Sensuous: Perception and Language in a More-than-Human World. New York: Pantheon.

Aristoteles (2005). Nikomakhoksen etiikka. Suom. S. Knuuttila. Helsinki: Gaudeamus
Bassham, G. (2013). Virtue-Centered Approaches to Education: Prospects and Pitfalls. Teoksessa M. W. Austin (toim.) Virtues in Action. New Essays in Applied Virtue Ethics. New York: Palgrave Macmillan, 11-22.

Berges, S. (2015). A Feminist Perspective on Virtue Ethics. New York: Palgrave Macmillan.

Cafaro, P. (2010). Environmental Virtue Ethics Special Issue: Introduction. Journal of Agricultural and 
Environmental Ethics, 23(3), 3-7. DOI: https://doi. org/10.1007/s10806-009-9204-3

Cannavò, P. (2016). Environmental Political Theory and Republicanism. Teoksessa T. Gabrielson \& C. Hall \& J. M. Mayer \& D. Schlosberg The Oxford Handbook of Environmental Political Theory. DOI: 10.1093/ oxfordhb/9780199685271.013.20

Crowley, T. (2010). From "Natural" to "Ecosocial Flourishing": Evaluating Evaluative Frameworks. Ethics and the Environment, 15(1), 60-100.

Dillon, R. S. (2017). Feminist Approaches to Virtue Ethics. Teoksessa H. Snow (toim.) The Oxford Handbook of Virtue. DOI: 10.1093/ oxfordhb/9780199385195.013.15

Donovan, J. (2013). Eläinten oikeudet ja feministinen teoria. Teoksessa E. Aaltola (toim.) Johdatus eläinfilosofiaan. Helsinki: Gaudeamus.

Friedman, M. (2000). Feminism in Ethics. Conceptions of Autonomy. Teoksessa M. Fricker \& J. Hornsby (toim.) The Cambridge Companion to Feminism in Philosophy. Cambridge, UK: Cambridge University Press, 205-224.

Friman, M. (2004). Aikamme hyveet korostavat sopeutumista työelämään ja omaa menestymistä. Aikuiskasvatus, 24(2), 164-168. https://doi. org/10.33336/aik.93556

Fullan, M. 1993. Why Teachers Must Become Change Agents. Educational leadership, 50(6), 12-17.

Gomes, M. \& Kanner, A. (1995). The Rape of the WellMaidens: Feminist Psychology and the Environmental Crisis. Teoksessa T. Roszak \& M. Gomes \& A. Kanner (toim.) Ecopsychology. Restoring the Earth, Healing the Mind. San Francisco: Sierra Club Books, 111121.

Haila, Y. (2009). Ekososiaalinen näkökulma. Teoksessa I. Massa (toim.) Vihreä teoria. Gaudeamus: Helsinki, 261-287.

Hatten-Flisher, J. \& Martusewicz, R. A. (2018). Ecofeminism and education. Oxford research encyclopedia: Education. https://doi.org/10.1093/ acrefore/9780190264093.013.136

Harvester, L. \& Blenkinsop, S. (2010). Environmental Education and Ecofeminist Pedagogy: Bridging the Environmental and the Social. Canadian Journal of Environmental Education 15, 120-134.

Huttunen, R. \& Kakkori, L. (2007). Aristoteles ja pedagoginen etiikka. https://netn.fi/sites/www.netn. fi/files/netn-2007-1.pdf. Niin \& Näin 1, 87-94.

Ingold, Tim. (2002). The Perception of Environment. Essays on Livelihood, Dwelling and Skill. London: Routledge.

IPCC (2019). Global Warming of $1.5^{\circ} \mathrm{C}$. https://www. ipcc.ch/site/assets/uploads/sites/2/2019/06/SR15_ Full_Report_High_Res.pdf
Jordan, K. \& Kristjánsson, K. (2017). Sustainability, Virtue Ethics, and the Virtue of Harmony with Nature. Environmental Education Research, 23(9), 1205-1229.

Kylänpää, R. (2017). Pentti Linkola - ihminen ja legenda. Helsinki: Siltala

Launonen, L. (2000). Eettinen kasvatusajattelu suomalaisen koulun pedagogisissa teksteissä 1860-luvulta 1990-/uvulle. https://jyx.jyu.fi/ handle/123456789/42028. Jyväskylä: Jyväskylän yliopisto.

Maclntyre, A. (2004). Hyveiden jäljillä. Moraaliteoreettinen tutkimus. Suom. N. Noponen. Helsinki: Gaudeamus.

MacIntyre, A. (2002a). A Short History of Ethics. London: Routledge

Maclntyre, A. (2002b). Dependent Rational Animals. Why Human Beings Need the Virtues. Chicago: Open court

Martusewicz, R. \& Edmundson, J. \& Lupinacci J. (2015). EcoJustice Education. Toward diverse, democratic, and sustainable communities. 2. painos. New York and London: Routledge

Mies, M. \& Shiva, V. (2005). Ecofeminism. London: Zed books

Matthies, A.-L. \& Närhi, K. \& Ward, D. (2001). The Ecosocial Approach in Social Work. Jyväskylä: Sophi.

Merchant, C. (1983). The Death of Nature. Women, Ecology, and the Scientific Revolution. San Francisco: Harper \& Row publishers.

Morton, T. (2010). The Ecological Thought. Cambridge: Harvard University Press.

Noddings, N. (1986). Caring. A Feminine Approach to Ethics \& Moral Education. Berkeley: University of California Press.

Nordström, L. \& Dorf, M. (2014). Elämämme perusteista. Tampere: Palladium kirjat.

Ojanen, E. (2000). Onko meillä malttia sivistykseen? Helsinki: Kansanvalistusseura

Platon (1999). Valtio. Suom. M. Itkonen-Kaila. Helsinki: Otava.

Plumwood, V. (2002). Environmental Culture: The Ecological Crisis of Reason. London: Routledge.

Pulkki, J. (2020). Varsinainen minä ja henkisyys ekososiaalisen kasvatusfilosofian aspekteina. Kasvatus, 51(3), 302-316.

Pulkki, J. \& Varpanen, J. \& Mullen, J. (2020). Ecosocial Philosophy of Education: Ecologizing the Opinionated Self. Studies in Philosophy and Education. https://doi. org/10.1007/s11217-020-09748-3

Pulkki, J. (2017). Kilpailun kasvatuksellisista ongelmista. Hyveitä 2000-luvulle. Tampere: Tampere University Press. 
Rolston III, H. (2005). Chapter 4. Environmental Virtue Ethics: Half the Truth but Dangerous as a Whole. Teoksessa R. Sandler \& P. Cafaro (toim.) Environmental Virtue Ethics. Lanham: Rowman and Littlefield Publishers, 61-78.

Salonen, A. \& Bardy, M. (2015). Ekososiaalinen sivistys herättää luottamusta tulevaisuuteen. Aikuiskasvatus, 35(1), 4-15. https://doi.org/10.33336/aik.94118

Salonen, A. (2013). Ekososiaalinen sivistys kulttuurin kulmakiveksi. Teoksessa M. Laine \& P. Toivanen (toim.) Kestävä kasvatus - kulttuuria etsimässä. Suomen Kulttuuriperintökasvatuksen seuran julkaisuja 6, 40-69.

Salonen, A. O. (2012). Sosiaalinen saneeraus - tie ekososiaaliseen sivistykseen. Teoksessa T. Helne \& T. Silvasti Yhteyksien kirja. Etappeja ekososiaalisen hyvinvoinnin polulla. Helsinki: Kelan tutkimusosasto, 134-147.

Sandler, R. L. (2013). Environmental Virtue Ethics. Teoksessa H. Lafollette (toim.) International Encyclopedia of Ethics. https://doi. org/10.1002/9781444367072.wbiee090

Sewall, L. (1995). The Skill of Ecological Perception. Teoksessa T. Roszak \& M. Gomes \& A. Kanner Ecopsychology. Restoring the Earth, Healing the Mind. San Francisco: Sierra Club Books, 201-215.

Sihvola, J. (2004). Alasdair Maclntyre moraalifilosofina. Teoksessa A. Maclntyre Hyveiden jäljillä. Moraaliteoreettinen tutkimus. Suom. N. Noponen. Helsinki: Gaudeamus, 7-13.

Sihvola, J. (2003). Miksi talous jäi filosofian sokeaksi pisteeksi? Hyveen ja liiketoiminnan välisen kuilun historiallinen tausta. Teoksessa I. Haavisto (toim.) Hyve ja markkinatalous. Helsinki: Taloustieto Oy, 19-29.

Takkinen, K. \& Takkinen, P. (toim.) (2015). Elonkehän puolesta. Syväekologisen kulttuurilehden kaksi vuosikymmentä Linkolasta Vadéniin. Vihreän elämänsuojelun liitto ry. Elonkehä kirjat.

Taylor, P. (1997). Luonnon kunnioittamisen etiikka. Teoksessa M. Oksanen \& M. Rauhala-Hayes (toim.) Ympäristöfilosofia. Kirjoituksia ympäristönsuojelun eettisistä perusteista. Helsinki: Gaudeamus, 225-250.

Tessman, L. (2005). Burdened Virtues. Virtue Ethics for Liberatory Struggles. Oxford, New York: Oxford University Press.

Toiskallio, J. (2016). Hyvä elämä, toimintakyky, sivistys. Teoksessa A. Mutanen, M. Kantola, H. Kotila \& L. Vanhanen-Nuutinen (toim.) Hyvä elämä, käytäntö, tutkimus ja ammattipedagogiikka. Turun ammattikorkeakoulun tutkimuksia 44. Turku, 47-68.
Vainio, O. P. (2016). Hyve-etiikka. Filosofia.fi. https:// filosofia.fi/node/7187

Varela, F. (1999). Ethical Know-How: Action, Wisdom and Cognition. Redwood City: Stanford University Press.

Vadén, T. (toim.) (2008). Linkolan ajamana. Helsinki: Into.

Vadén, T. (2009). "Ihmiskunta on luonut korkeakulttuureja ilman polttomoottoreita" - Yksi kokemusperäinen elämänfilosofia - Haastattelussa Lasse Nordlund. Niin \& Näin 4, 6-12.

Värri, V.-M. (2018). Kasvatus ekokriisin aikakaudella. Tampere: Vastapaino.

Värri, V.-M. (2011). Vastuu ihmisen mittana. Kasvatusteoreettisia ja filosofisia näköaloja ekologiselle sivistysprojektille. Tiedepolitiikka 4, 27-35.

Värri, V.-M. (1994). Menonin paradoksi "neliulotteisessa" kasvatustodellisuudessa. Niin \& Näin 2, 58-59.

Väyrynen, K. (2014). Hyveet ympäristöetiikassa. Teoksessa N. Hämäläinen \& J. Lemetti \& I. Niiniluoto (toim.) Hyve. Filosofisia tutkimuksia Helsingin yliopistosta 1458.

Väyrynen, K. (2006). Ympäristöfilosofian historia Maaäitimyytistä Marxiin. Tampere: Niin \& Näin.

Warren, K. \& Cheney, J. (1991). Ecological Feminism and Ecosystem Ecology. Hypatia, 6(1), 179-197.

Warren, K. (1990). The Power and Promise of Ecological Feminism. Environmental Ethics, 12(3), 125-146.

Wensveen, van, L. (2000). Dirty virtues. The emergence of ecological virtue ethics. Amherst: Humanity Books.

Wilenius, R. (2002). Miten käy lasten ja nuorten? Keskustelua ja filosofiaa kasvatuksesta. Helsinki: Dialogia.

Wilenius, R. (1987). Kasvatuksen ehdot. Kasvatusfilosofian luonnos. Jyväskylä: Atena.

Wilenius, R. (1982). Ihminen ja sivistys. Jyväskylä: Gummerus.

von Wright, G. H. (1987). Tiede ja ihmisjärki. Suunnistusyritys. Helsinki: Otava.

Zagzebski, L. (2010). Exemplarist Virtue Theory. Metaphilosophy. Special issue: Virtue and vice, moral and epistemic 41(1/2), 41-57. 
1 Homo mensura -ajatus eli "ihminen on kaiken mitta" tulee antiikin filosofi Protagorakselta.

2 Ympäristöhyve-etiikka on suomennos sanasta environmental virtue-ethics. Vakiintunutta käännöstä sanalle ei vielä ole, ja ympäristöhyve-etiikka on myös suomennettu ympäristölliseksi hyve-etiikaksi (Arto Naskali http://janka. fi/arkistot/807). Kari Väyrynen (2014) on puhunut ympäristöystävällisestä hyve-etiikasta ja ympäristötietoisesta hyve-etiikasta. Joskus puhutaan virtuismista. Latva-Mäenpää puhuu filosofian pro gradu -työssään (2020) esimerkiksi "Sandlerin hyve-eettisesti orientoituneesta etiikasta" (ks. Sandler 2013) sekä "ympäristö-hyveetiikasta". https://www.utupub.fi/bitstream/handle/10024/150380/opinn\%c3\%83\%c2\%a4ytety\%c3\%83\% c2\%b6.pdf?sequence=1\&isAllowed=y). Nähdäkseni ympäristöhyve-etiikan käsite, jonka kuulin vuonna 2019 yksityiskeskustelussa filosofi Lauri Lahikaiselta, on selkeä, konstailematon ja sujuvakielinen käännös, joten käytän sitä. Kiitänkin Lahikaista, Aikuiskasvatuksen toimituskuntaa sekä anonyymia vertaisarvioijaa käsitteen suomentamiseen liittyvistä huomioista.

3 Hyve-etiikka on siinä mielessä inmiskeskeistä, että tarkastelun kohteena ovat ihmisten hyveet ja paheet. Mutta ekososiaalisen hyve-etiikan ja ympäristöhyve-etiikan perusajatus on sellaisten hyveiden pohtiminen, joissa ymmärretään muidenkin eliöiden kuin ihmisten tarpeet ja etu.

4 ECER-konferenssissa Hampurissa 2019 Arjen Wals piti keynote puheenvuoron: "Should and Can Education Save the Planet". Tietämättä suomalaisista ekologisen ja ekososiaalisen sivistyksen käsitteistä hän puhui sellaisten tarpeesta. Esitelmästä jäi kuva, että suomalainen tutkimus kestää hyvin kansainvälisen vertailun: https://www. youtube.com/watch?v=D1 daDIQaFmU

5 Suomennos omani.

6 Lajisorto eli spesisismi tarkoittaa olennon arvon ja merkityksen määrittelemistä sen perusteella, mihin lajiin tämä kuuluu. Spesisismistä puhutaan samaan tapaan kuin seksismistä ja rasismista ennakkoluulojen osoittamisen yhteydessä.

7 Jälkikoloniaalinen ajattelu eli postkolonialismi viittaa siirtomaajärjestelmän purkautumisen jälkeiseen aikaan, jossa nähdään jatkumo kolonialistisen järjestelmän sekä tämän jälkeisten taloudellisten, kulttuuristen ja sosiaalisten suhteiden välillä.

8 Näkökulma on tietysti ihmiskeskeinen, eikä kaikki ihmiskeskeisyys ole paheellista. Paheelliseksi ihmiskeskeisyys voidaan lukea silloin, kun siitä seuraa muun elämän hyvinvoinnille piittaamattomia ajatuksia ja toimia.

9 Suomennos omani.

10 Pentti Linkolan ajattelussa olikin ekologisten tekijöiden ja ihmisen hyvän välinen ristiriita ja nähdäkseni liian pitkälle menevä ekologian painotus tai liian vähäinen ymmärrys ihmisen sosiaalisesta maailmasta.

11 Jean-Jacques Rousseau (1712-1778) puhui valtion yleistahdosta Yhteiskuntasopimus-teoksessaan, ja käsite sopisi tähänkin.

12 Pentti Linkola on esimerkiksi kritisoinut demokratiaa sen ekologisesta tuhoavuudesta.

13 Kukaan ei toki ole kaikkien mielestä kaikilta osin hyveellinen, mutta tähän valitut kuuluvat kaikkein tunnetuimpiin ja ikonisiin hahmoihin, joihin hyveet esimerkiksi populaarikulttuurissa yleisesti yhdistetään.

14 Platonin Valtio-teoksen toisen kirjan Stephanus-numeroinnin mukaiset kohdat 376d-378d

15 Sukupuolitettu hyveen ajatus on tietysti hankala ja moniselitteinen asia (esim. Dillon 2017). Mutta esimerkiksi huolenpidon etiikka (ethics of care) on tunnettu feministisen etiikan muoto, jota kasvatuksessa on tarkastellut esim. kasvatusfilosofi Nel Noddings (1986). Huolenpito ei perimmiltään ole sukupuolisidonnainen asia.

16 Suhtaudun systeemiajatteluun jokseenkin varauksellisesti, koska lineaariset rationaaliset käytännöt eivät aina tee oikeutta luonnon monimutkaisille orgaanisille vuorovaikutussuhteille. Järjestys, jota systeeminen ajattelu korostaa, tarkoittaa ekofeministien kritisoimaa hierarkkista hallintaa. Sen sijaan suhteita korostava paradigma ei yritä sovittaa ympäristöä kaiken ylitse käyvään paradigmaan, vaan kunnioittaa elämän orgaanista kiemuraisuutta ja monikerroksisuutta. (Ks. Donovan 2013, 201.) Systeemiajattelulla on varmasti etunsa, ja se sopinee monille. Toisaalta filosofinen ja kokonaisuuksien hahmottamiseen pyrkivä ajattelu on toinen tapa ja pyrkimys tarkastella luontoa kokonaisvaltaiseen ymmärrykseen tähtäävällä tavalla.

17 Markku Niinivirta väitteli kasvatustieteen alalta teemanaan fronesis: https://trepo.tuni.fi/handle/10024/102295

18 Biologinen alue, eli bioalue, tulee englannin sanasta bioregion. Se tarkoittaa eri periaattein ekologisesti ja maantieteellisesti rajattua aluetta sekä tämän monilajisia asukkaita. Bioalue liittyy bioregionalistiseen ajatteluun, jonka mukaan ihmisyhteisön tulisi tyydyttää tarpeitaan mahdollisimman paljon niistä resursseista, jotka sitä ympäröivällä bioalueella on tarjottavana. Esimerkiksi lähiruokatrendi liittyy bioregionalistiseen ajatteluun. (ks. https://www.elonkeha.com/2016/03/18/bioregionalismi-lyhyt-oppimaara) 